\title{
M\&A, Institutional Investor and Executive Compensation
}

\author{
Qiwen Hu and Yongsheng Ge* \\ East China University of Science And Technology, P.R.China \\ ${ }^{*}$ Corresponding author
}

\begin{abstract}
The article try to explore the impact of M\&A on executive compensation and further study the influence of institutional investors on the relationships between $M \& A$ and executive compensation. The study finds that the change in executive compensation has a significant positive correlation with M\&A behavior, which reflects the fact that executives may tend to have self-interest in the event while the involvement of institutional investors will alleviate this problem. This study provides empirical evidence for institutional investor activism theory and the direction for corporate governance in M\&A.
\end{abstract}

Keywords-M\&A; executive compensation; institutional investor

\section{INTRODUCTION}

As an important part of the mature market economy, the M\&A (mergers and acquisitions) market has always been the focus of researchers in academia. Actually, M\&A has brought about a sharp rise in the salaries of senior management of the company. However the performance of the company after M\&A has shown a flat or sharp decline. Meanwhile, the expansion of the scale by M\&A, which can be regarded as a good excuse, is an important reason for executives to get promotion and salary increase. So executives have strong motives to increase the salary of the company through the expansion of the company's assets, regardless of the negative influence of M\&A on shareholder value[1].In this case, researchers begin to find ways to reduce this negative effects. "Li ShanMin(2009) argues that although executives' shareholdings cannot completely reverse the situation of destroying shareholder value, they can be alleviated to a certain extent[2]. The latest research finds that the introduction of director responsibility executive insurance also has a positive effect[3].On the other hand, institutional investors play increasingly important role in governance. In the early research stage, scholars at home and abroad find that the evidence of institutional investors actively participating in corporate governance is not sufficient[4]. And with more academic research, there're different voice on this problems. One is that when there is business dealings between the institutional investors and the executives, the institutional investors may make decisions that are not conducive to external shareholders[5]. Another one is that institutional investors may actively participate in corporate governance activities to monitor corporate executive behavior in order to obtain better returns[6]. According to the article from [7], institutional investors may exert influence on corporate governance by influencing the board of directors, management compensation, mergers and acquisitions, capital institutions.
Therefore, this paper try to study the effect of M\&A on executive compensation, and the mechanism of institutional investors' relationship between M\&A and executive compensation, using Shanghai-Shenzhen A-share listed companies from 2013 to 2017 as samples. Hoping the results can enrich corporate governance theory and provide empirical evidence to positive role of institutional investors in takeover activity.

\section{HYPOTHESES}

As the decision makers and implementers of corporate activities, managers play a major role in corporate M\&A activities. Therefore, an increasing number of scholars are paying attention to the impact of executives on M\&A. Generally speaking, the expansion of the scale is an important reason for executives to get promotion and salary increase. And there are two main ways for enterprises to expand their scale, one is to continuously expand the scale of enterprises through internal accumulation, and the other is to merger other company in a short time. As to CEOs, the latter is a better choice obviously for its more direct and efficient way. Consequently managers are likely to take advantages of M\&A to seek opportunities to improve their salaries, which has been confirmed by many researchers. Reference [8] finds that executives will have an increase in compensation following takeover due to increased firm size using a sample of UK firms making acquisitions in the 1999-2000 period. On the other hand, Many studies shows that executive compensation is not linked to $M \& A$ performance, indicating that there is likely to be a large agency cost in M\&A [9]. Reference [10]documents that executives can also benefit from M\&A multiple times, regardless of whether the merger is successful or not. Reference [11] find that 39\% of corporate executive compensation will be improved after M\&A , no matter what difficulties of takeovers or executives' talents are, which has also been supported by the empirical evidence from China [12]. These studies further prove that the self-interested motives of executives do exist and M\&A does provide an opportunity for executives to increase their own compensation. Based on these analysis, we hypothesize that:

$\mathrm{H} 1$ : The size of the company significantly affects executive compensation changes, and there is a significant relationship between M\&A and executive compensation.

As a emerging corporate governance mechanism, institutional investors become the focus in academia. As an institutional investor, on the one hand, it has a strong supervisory motive because institutional investors held a large number of shares of a single company and undertake certain liquidity risks 
which means once the invested company suffers from sharp fall of stock price, the institutional investors need to bear the loss mutually. On the other hand, the advantage of information and professional ability makes them highly capable of supervision[13]. Therefore, institutional investors have strong supervisory motivation and great capacity of supervision, which makes it possible for institutional investors to actively participate in corporate governance and alleviates principalagent problem, supported by existing research[14].The governance role of institutional investors is also reflected in corporate M\&A activities. Reference [15] indicates that institutional investors, especially transactional institutional investors, have a positive correlation with M\&A performance in state-owned enterprises, showing a certain governance effect. In the meantime Gaspar (2005) argues that long-term institutional investors have played an positive role in the company's control market, with reduction of the management's excessive M\&A that damage the company's value[16]. Furthermore,Qiu (2008)indicates that large public pension funds can reduce bad mergers[17]. Above all, we believe that the increase in executive compensation in M\&A stems from the principal-agent problem which can explain precisely that the executives only take selfinterest into account regardless of shareholder value when they make M\&A decision. Considering the increasement of institutional investors, we have reasonable grounds to believe institutional investor can restrain the self-interested behavior of executives in M\&A. We propose our second hypothesis:

H2: The higher the shareholding ratio of institutional investors, the smaller changes of executive compensation growth in M\&A activities.

\section{DATA DESCRIPTION AND VARIABLES}

\section{A. Data Descroption}

This paper selects the Shanghai-Shenzhen A-share listed company from 2013 to 2017 as the initial sample and removes the sample with the following conditions:(1)Samples with missing data; (2) ST companies; (3) Financial industry data; (4) the company that doesn't pay in cash; (5) Samples with a total price of M\&A transactions less than 5\% of the acquirer's net assets. In order to eliminate the effect of abnormal value, this paper processes continuous variables in the range of $0 \sim 1 \%$ and $99 \%$ 100\% using the order of winsor, and finally obtains 7,907 valid samples. All of data comes from the CSMAR and the RESSET database, and we processed data by stata12.

\section{B. Method and Measurement of Variables}

$$
\begin{aligned}
\text { DCOM }_{t} & =\alpha_{0}+\alpha_{1} M A_{t-1}+\alpha_{2} \text { Lnsize }_{t}+\alpha_{3} \text { Lev }_{t}+\alpha_{4} \text { ROA }_{t} \\
& +\alpha_{5} \text { GroLL L }_{t-1}+\alpha_{6} \text { Own }_{t}+\alpha_{7} \text { Own1__ }{ }_{t}+\alpha_{8} \text { Current } \\
& +\alpha_{9} \text { Tobinq }+\varepsilon_{t}
\end{aligned}
$$

DCOM $_{t}=\beta_{0}+\beta_{1} M A_{t-1}+\beta_{2}$ Inshare $_{t}+\beta_{3} M A_{t-1} *$ Inshare $_{t}$ $+\beta_{4}$ Lnsize $_{t}+\beta_{5}$ Lev $_{t}+\beta_{6}$ ROA $_{t}+\beta_{7}$ GroL $_{t-1}+$ $\beta_{8}$ Own1_t $t_{t}+\beta_{9}$ Own1_2 ${ }_{t}+\beta_{10}$ Tobinq $+\beta_{11}$ Dual $_{t}$ $+\beta_{12}$ IndeBoard $_{t}+\varepsilon_{t}$

Eq.(1) describes the model used to test the relationships between M\&A activities and executive compensation. Eq.(2) describes the relationship between the share held by institutional investor and compensation in M\&A deals. We take the M\&A as a dummy variable, and the variables about income growth rate adopt the data of the lag phase, and the rest of the variables are the data of the current year. And we measures the compensation by dividing the maximum top three executive compensation by 100,000 . The definition and calculation of each variable are

\begin{tabular}{|c|c|}
\hline code & Variable definition and calculation \\
\hline DCOM & $\begin{array}{l}\text { The top } 3 \text { executives with the highest amount of } \\
\text { compensation / 100,000 }\end{array}$ \\
\hline MA & $\begin{array}{l}\text { If the company had a merger in the previous year,it has } \\
\text { been assigned the value } 1\end{array}$ \\
\hline lnsize & $\begin{array}{l}\text { The total assets at the end of the year are taken from the } \\
\text { natural logarithm }\end{array}$ \\
\hline Inshare & $\begin{array}{c}\text { Total number of A shares held by institutional investors / } \\
\text { total number of A shares }\end{array}$ \\
\hline Lev & Total liabilities / total assets \\
\hline ROE & Net profit / average balance of shareholders' equity \\
\hline Tobinq & Market value/asset total \\
\hline Own1 & The shareholding ratio of the largest shareholder \\
\hline Own1_2 & $\begin{array}{c}\text { The square of the shareholding ratio of the largest } \\
\text { shareholder }\end{array}$ \\
\hline Current & Current assets / current liabilities \\
\hline GroL & $\begin{array}{l}\text { (increased operating income / total operating income of the } \\
\text { previous year) }\end{array}$ \\
\hline Actrl & $\begin{array}{l}\text { If the actual controlling person is state-owned enterprise, } \\
\text { it has been assigned the value } 1\end{array}$ \\
\hline Dual & $\begin{array}{l}\text { If the chairman and general manager are the same person, it } \\
\text { has been assigned the value } 1\end{array}$ \\
\hline IndeBoard & Number of independent directors / total number of directors \\
\hline
\end{tabular}
shown in Table I .

TABLE I. VARIABLE DEFINITION

\section{EMPIRICAL RESULTS}

\section{A. Sample Characteristic}

TABLE II. SUMMARY STATISTICS

\begin{tabular}{l|cccccc}
\hline VARIABLES & $\mathbf{N}$ & mean & sd & max & min & p50 \\
\hline DCOM & 7,907 & 18.03 & 11.92 & 54.37 & 5.4 & 14.52 \\
MA & 7,907 & 0.555 & 0.497 & 1 & 0 & 1 \\
Insize & 7,907 & 22 & 1.161 & 26.23 & 19.64 & 21.85 \\
Inshare & 7,907 & 0.245 & 0.222 & 0.82 & 0 & 0.169 \\
lev & 7,907 & 0.421 & 0.212 & 0.914 & 0.0517 & 0.406 \\
ROA & 7,907 & 0.036 & 0.050 & 0.187 & -0.153 & 0.032 \\
Tobinq & 7,907 & 2.818 & 3.626 & 192.9 & 0.00695 & 2.049 \\
Own1 & 7,907 & 0.338 & 0.145 & 0.84 & 0.086 & 0.318 \\
\hline
\end{tabular}

It is not difficult to find from Table II that the mean and median of the variable DCOM are 18.03 and 14.52 respectively, and the maximum and minimum values are 54.37 and 4.5, indicating that the executive compensation has raised at a rapid speed in recent years. Summary statistics for the M\&A activities presents that $5.5 \%$ of the companies had M\&A activities during the sample period, indicating that M\&A in the capital market is very frequent. The average shareholding ratio of institutional investors reaches to $24.5 \%$, indicating that institutional investors in China play an increasingly important role in the capital market. Those evidence also demonstrates their ability and willingness to participate in corporate governance. 


\section{B. Pearson Correlation}

Avoiding the existence of multicollinearity between variables to adversely affect the regression results, we analyze the correlation of the main variables. As we can see in table3,the correlation coefficient between most variables is significant. DCOM is significantly positively correlated with MA, Insize, and lnshare, consistent with the expected sign of the variables in the model above. But this is only a correlation analysis, and the specific coefficient estimates are given in the regression analysis Table III shows that the correlation coefficients between the variables are much less than 0.5 , which is enough to show that there is no multicollinearity between the variables.

TABLE III. PEARSON CORRELATION ANALYSIS

\begin{tabular}{|c|c|c|c|c|c|c|c|c|}
\hline & DCOM & MA & Insize & Inshare & lev & ROA & Tobinq & Own1 \\
\hline DCOM & 1 & & & & & & & \\
\hline MA & $0.4149 *$ & 1 & & & & & & \\
\hline Insize & $0.4243^{*}$ & $0.2441^{*}$ & 1 & & & & & \\
\hline Inshare & $0.1896^{*}$ & $0.1273^{*}$ & $0.2025^{*}$ & 1 & & & & \\
\hline Lev & $0.1165^{*}$ & $0.0694 *$ & $0.5224^{*}$ & $0.0514^{*}$ & 1 & & & \\
\hline ROA & $0.2217^{*}$ & $0.0830^{*}$ & -0.0023 & $0.0813^{*}$ & $0.3718^{*}$ & 1 & & \\
\hline Tobinq & $0.0785^{*}$ & $0.0490^{*}$ & $0.4064^{*}$ & 0.0046 & $0.2952 *$ & $0.1598^{*}$ & 1 & \\
\hline Own1 & $0.0337 *$ & $0.0557 *$ & $0.2197 *$ & $0.0981^{*}$ & $0.0899 *$ & $0.0870 *$ & $0.1019 *$ & 1 \\
\hline
\end{tabular}

\section{Regression Results}

1) Executive compensation in $M \& A$ : Table IV presents the regression results of the relationship between M\&A and executive compensation using three groups data including all the samples and samples that have been divided by M\&A. The regression result shows that the coefficient of M\&A has predicted signs and is statistically significant, which suggests that firms with M\&A have greater changes of executive compensation. And we also find that the size of the company in the M\&A company is the main factor affecting the compensation growth, comparing to the company without M\&A. To a certain extent, the results indicates that the company executives have a strong incentive to achieve rapid salary growth by implementing M\&A. The size of the company and M\&A are significantly positively correlated with executive compensation, which are consistent with first Hypothesis in this article.

TABLE IV. TABLE4 REGRESSION RESULTS OF MODEL1

\begin{tabular}{lccc}
\hline VARIABLES & $\begin{array}{c}\text { All } \\
\text { samples }\end{array}$ & MA=1 & MA=0 \\
\hline MA & $6.754^{* * *}$ & & \\
& $(0.228)$ & & \\
Insize & $3.728^{* * *}$ & $4.715^{* * *}$ & $2.594^{* * *}$ \\
& $(0.141)$ & $(0.216)$ & $(0.181)$ \\
Lev & $-1.469 *$ & -1.121 & $-2.098^{* *}$ \\
& $(0.781)$ & $(1.286)$ & $(0.935)$ \\
ROA & $15.38^{* * *}$ & $20.49^{* *}$ & 8.576 \\
& $(5.037)$ & $(8.138)$ & $(6.123)$ \\
GroL & $-0.213^{* * *}$ & $-0.258^{* *}$ & -0.151 \\
& $(0.0799)$ & $(0.119)$ & $(0.102)$ \\
Own1 & $-17.52^{* * *}$ & $-20.46^{* * *}$ & $-12.18^{* * *}$ \\
& $(3.180)$ & $(4.742)$ & $(4.055)$ \\
Tobinq & $0.130^{* * *}$ & $0.389^{* * *}$ & 0.0333 \\
& $(0.0353)$ & $(0.0791)$ & $(0.0353)$ \\
Constant & $-79.24 * * *$ & $-105.2 * * *$ & $-52.71 * * *$ \\
& $(4.619)$ & $(11.38)$ & $(5.164)$ \\
Observations & 7,872 & 4,371 & 3,501 \\
Year & Control & Control & Control \\
Industry & Control & Control & Control \\
R-squared & 0.395 & 0.316 & 0.240 \\
\hline
\end{tabular}

2) Institutional investors: To figure out the relationship between institutional investors and change of executive compensation in the M\&A activities, we use cooperative modes of M\&A and proportion of shareholding of institutional investor in regression equation as in (2).

TABLE V. REGRESSION RESULTS OF MODEL2

\begin{tabular}{|c|c|c|}
\hline VARIABLES & (1) & (2) \\
\hline \multirow[t]{2}{*}{ MA } & $6.699 * * *$ & $4.207^{* * *}$ \\
\hline & $(0.227)$ & $(0.256)$ \\
\hline \multirow[t]{2}{*}{ Inshare } & $4.448 * * *$ & $5.952 * * *$ \\
\hline & $(0.555)$ & $(0.547)$ \\
\hline \multirow[t]{2}{*}{ MA* Inshare } & & $-0.471 * * *$ \\
\hline & & $(0.0240)$ \\
\hline \multirow[t]{2}{*}{ Insize } & $3.605^{* * *}$ & $3.441 * * *$ \\
\hline & $(0.141)$ & $(0.138)$ \\
\hline \multirow[t]{2}{*}{ lev } & $-1.456 *$ & $-1.259 *$ \\
\hline & $(0.778)$ & $(0.760)$ \\
\hline \multirow[t]{2}{*}{ ROA } & $15.28 * * *$ & $10.98 * *$ \\
\hline & $(5.017)$ & (4.903) \\
\hline \multirow[t]{2}{*}{ GroL } & $-0.214 * * *$ & $-0.218 * * *$ \\
\hline & $(0.0796)$ & $(0.0777)$ \\
\hline \multirow[t]{2}{*}{ own1 } & $-19.25 * * *$ & $-16.97 * * *$ \\
\hline & (3.175) & (3.102) \\
\hline \multirow[t]{2}{*}{ own1_2 } & $21.75 * * *$ & $18.24 * * *$ \\
\hline & $(4.080)$ & (3.987) \\
\hline \multirow[t]{2}{*}{ tobinq } & $0.114^{* * *}$ & $0.111^{* * *}$ \\
\hline & $(0.0352)$ & $(0.0344)$ \\
\hline \multirow[t]{2}{*}{ dual } & -0.361 & -0.255 \\
\hline & $(0.245)$ & (0.239) \\
\hline \multirow[t]{2}{*}{ indepBoard } & $-3.731 *$ & -2.450 \\
\hline & (2.037) & (1.990) \\
\hline \multirow[t]{2}{*}{ Constant } & $-76.15 * * *$ & $-69.16^{* * *}$ \\
\hline & (4.617) & (4.521) \\
\hline Year & Control & Control \\
\hline Industry & Control & Control \\
\hline Observations & 7,872 & 7,872 \\
\hline R-squared & 0.400 & 0.428 \\
\hline
\end{tabular}

Table $\mathrm{V}$ presents the results that he regression coefficients of M\&A are significantly greater than 0 , further confirming hypothesis1.And the coefficient of MA*lnshare is positive at the 
$1 \%$ significance level, suggesting that with the increasement of proportion of shares held by institutional investor, there is a quite reduction of executive compensation changes in M\&A. As a consequence, we believe that institutional investor can inhibit the self-interest behavior of executives in M\&A, supporting the second hypothesis in this paper.

\section{Robustness}

To improve the robustness, we repeat the regressions using other measures of executive compensation due to the differences of definition of executives at home and abroad . we use the maximum top three executive compensation and total compensation of all the directors, supervisors and senior managers in place. Besides, we also use proportion of share held by independent institutional investors to measure the influence of institutional investor. Finally we find the main conclusion has not changed.

\section{CONCLUSION}

This paper selects the 2013-2017 Shanghai and Shenzhen A-share listed companies as data samples, analyzes and verifies the relationship between the company's M\&A behavior and executive compensation changes, and the influence of institutional investors' intervention on this relationship. We find that executives prefer to implement M\&A to expand the company scale and obtain reasonable excuses for their own salary improvement. On the other hand, the governance effect of institutional investors is also reflected in M\&A. The increase in the shareholding ratio of institutional investors has played a certain role in restraining the growth of executive compensation in M\&A.

Due to the existence of the principal-agent problem, executives tend to take use of M\&A to acquire more personal interests, without standing in the perspective of shareholders, this means that M\&A activities hardly create value but damage it. In addition, based on the previous research, this paper further proves the positive role of institutional investors in M\&A to restrain executive self-interest behavior.

\section{REFERENCES}

[1] Cheng S, Indjejikian R J. The Market for Corporate Control and CEO Compensation: Complements or Substitutes?[J]. Contemporary Accounting Research, 2010, 26(3):701 728.

[2] Li ShanMin, Mao Y J. Executive Equity-Based Compensation ,Executive Private Benefits and Corporate M\&As[J]. Journal of Management Science, 2009,22(6):2 12

[3] Hao Zhaojun, Guoliu. A Study on the Relationship among D\&O Liability Insurance, Private benefits and Corporate M\&As[J]. Insurance Studies, 2014,12(9):.78 89

[4] Short H, Keasey K. Managerial ownership and the performance of firms: Evidence from the UK[J]. Journal of Corporate Finance, 1999, 5(1):79 101.

[5] Tang Qingquan, Luo Danglun. The tunneling of cash dividends and the dividend of controlling shareholders[J]. Finance \& Trade Research, 2006(01):92 97.

[6] Zhang Huijuan, Zhang Ran .Private equity and executive compensation contracts of invested enterprises:Based on the perspective of corporate governance [J].Management World,2012(09):156-167

[7] Yi Zhihong, Li Yanli. The Role of Institutional Investors in Corporate Governance: A Literature Review[J]. Management Review, 2013,25(05):60 71. Zhang Huijuan, Zhang Ran .Private equity and executive compensation contracts of invested enterprises:[J]. Management World, 2012(09):156-167

[8] Goh.Mergers, executive compensation, and post-merger performance of acquiring firms[J]. University of Cambridge, 2006.

[9] Han Liyan. What do Frequent Mergers and Acquisitions Mean?Evidence from Chinese Listed Companies[J]. China Economic Quarterly,2007,6(4):1185 1200.

[10] Guest P M. The Impact of Mergers and Acquisitions on Executive Pay in the United Kingdom[J]. Economica, 2010, 76(301):149 175.

[11] Grinstein Y, Hribar P. CEO compensation and incentives: Evidence from M\&A bonuses $\longleftarrow[\mathrm{J}]$. Social Science Electronic Publishing, 2004, 73(1):119 143.

[12] Li Xiaoyan , Tao J. Acquisition,Corporate Governance and Executive Rewards:A Comparative Study between State-owned Enterprises and Private Enterprises[J]. China Soft Science, 2011(05):122 128.

[13] Katz D A, Mcintosh L A. Corporate Governance: A Seismic Shift in the Mechanics of Electing Directors[J]. Venulex Legal Summaries, 2006.

[14] Wang J L, Shi Y D. Institutional Investors,Agency Costs and Company Value_-Empirical Study Based on Stochastic Frontier Model and Threshold Regression[J]. Chinese Journal of Management Science, 2016.

[15] Zhou Shaoni, ZhangQiusheng.Can Institutional Investors Promote M\&A Performance of State-owned Enterprises? [J].Accouting research, 2017(06):67 74+97

[16] Gaspar J M, Massa M, Matos P. Shareholder investment horizons and the market for corporate control $\underset{\xi}{\mathrm{s}}[\mathrm{J}]$. Journal of Financial Economics, 2005, 76(1):135 165.

[17] Qiu L X. Selection or Influence? Institutional Investors and Corporate Acquisitions[J]. Social Science Electronic Publishing, 2008. 